\title{
Genetic variation and inheritance characteristics for carbon isotope discrimination in alfalfa
}

\author{
DOUGLAS A. JOHNSON AND MELVIN D. RUMBAUGH
}

Authors are plant physiologist and research geneticist (retired), USDA-ARS, Forage and Range Research Lab., Utah State University, Logan 84322-6300.

\begin{abstract}
The negative correlation between carbon isotope discrimination $(\Delta)$ and water-use efficiency in $\mathbf{C}_{\mathbf{3}}$ species, including alfalfa (Medicago sativa $L_{\text {.), }}$, suggests that $\Delta$ might be useful in the selection of alfalfa cultivars that use water more efficiently. We initiated field experiments with alfalfa in northern Utah to determine genetic variation for $\Delta$ within representative breeding populations, the effect of drought on $\Delta$, magnitudes of heritability for $\Delta$, genetic regulation of $\Delta$, and how $\Delta$ differs among plant parts. In an experiment conducted under a rainout shelter facility equipped with a line-source sprinkler system, genetic variability for $\Delta$ was not detected in 15 clones each from the NC-83-1 germplasm and 'Spredor 2' cultivar. In another experiment with 25 clones from the NC-83-1 germplasm, there was significant $(P<0.01)$ genetic variation for $\Delta$ with a range of 1.6 per mil $(\%)$, and broad-sense heritabilities exceeded 0.80 . In a field trial with 78 cultivars and elite breeding lines, significant genetic variation for $\Delta$ was observed, although the range for $\Delta$ was only $0.8 \%$. We also detected significant genetic variation for $\Delta$ in a diallel experiment with 196 crosses from 14 parent clones from NC-83-1. Furthermore, general combining ability was significant, but specific combining ability and reciprocal effects were not, indicating that standard breeding techniques could be used to alter $\Delta$ response in alfalfa. Plant parts differed significantly for $\Delta$ with stems having the lowest value $(18.7 \%$ ) followed by the entire shoot $(19.0 \%)$, upper leaves $(19.4 \%)$, and bottom leaves $(20.2 \%)$. The lack of significant statistical interactions among plant parts suggested that any plant part could be sampled to determine $\Delta$. The results from these experiments indicated that promise exists for using $\Delta$ to improve water-use efficiency in alfalfa; however, use of more diverse germplasm may be necessary to expand opportunities for selection in North American alfalfa germplasm.
\end{abstract}

Key Words: Medicago sativa, carbon isotope ratio, water-use efficiency, transpiration efficiency

Alfalfa (Medicago sativa $\mathrm{L}$.) is the world's most important forage crop (Barnes et al. 1988) and is the only forage known to

Cooperative investigations of the USDA-ARS, USDA-Cooperative States Research Service (Grant No. 86-CSRS-2-2962), and Utah Agricultural Experiment Station, Journal Paper 4640.

Authors thank R. Howard Skinner, Kevin J. Connors, Bruce M. Pendery for their capable technical assistance.

Manuscript accepted 31 Jul. 1994. have been cultivated before recorded history (Michaud et al. 1988). Alfalfa is a widely adapted perennial legume that provides a high-quality forage, fixes atmospheric nitrogen, exhibits rapid growth after defoliation, and survives in dry, high-temperature environments. It persists well on rangelands once it is established (Miles 1969, Wilton et al. 1978, Rumbaugh and Pedersen 1979) and naturally reseeds itself on sites that receive as little as 280 mm annual precipitation (Rumbaugh 1982). Alfalfa is capable of fixing nitrogen on semiarid rangelands (Johnson and Rumbaugh 1981) and increases the forage and protein yields of associated crested wheatgrass [Agropyron cristatum (L.) Gaertner] (Rumbaugh et al. 1982). Because of its many attributes, alfalfa is recommended more frequently for range improvement projects than any other legume species (Rumbaugh and Townsend 1985).

Alfalfa is able to survive on semiarid rangelands probably because of its extensive root system and its ability to become semi-dormant during severe, prolonged periods of drought. Even so, alfalfa water use is considered relatively extravagant because its seasonal evapotranspiration is large compared to other crops (Sheaffer et al. 1988). However, early in the 1900s, Briggs and Shantz (1914) reported that alfalfa cultivars differed in their water-use efficiency or transpiration efficiency (amount of dry matter produced per unit of transpiration). Cole et al. (1970) also found significant differences in water-use efficiency among 5 cultivars and 2 experimental lines of alfalfa. Greater variation in water-use efficiency was detected within cultivars than among cultivars, which suggested that efficient genotypes could be used as germplasm to improve water utilization.

Despite the apparent variability for water-use efficiency in alfalfa, cultivars have not been specifically developed for high water-use efficiency. This probably is due to the lack of practical techniques for screening large breeding populations for water-use efficiency. Techniques such as gas exchange procedures can rapidly assess relationships between $\mathrm{CO}_{2}$ uptake and water loss, but these are instantaneous values that may not reflect integrated responses throughout the growing season. Pot-weighing techniques reliably evaluate water-use efficiency, but cannot accommodate the large number of breeding lines typically required in plant improvement programs.

One promising technique for indirectly evaluating water-use efficiency in $\mathrm{C}_{3}$ species involves analysis of the stable carbon isotope composition $\left({ }^{12} \mathrm{C}\right.$ and $\left.{ }^{13} \mathrm{C}\right)$ in plant tissues (Ehleringer et al. 1993). Farquhar et al. (1982) and Farquhar and Richards (1984) theorized that ${ }^{13} \mathrm{C}$ discrimination $(\Delta)$ should be negatively related to water-use efficiency because $\Delta$ and water-use efficiency are independently associated with leaf intercellular $\mathrm{CO}_{2}$ concentration. This negative association between $\Delta$ and water-use efficien- 
cy has been confirmed for many $\mathrm{C}_{3}$ crop species (Farquhar et al. 1989) and various cool-season grasses (Johnson and Asay 1993). Selection for low $\Delta$ has been proposed as a method to indirectly estimate long-term water-use efficiency and to select for improved water-use efficiency in breeding programs for $\mathrm{C}_{3}$ crop species. Johnson and Tieszen (1994) reported a significant negative association between $\Delta$ and water-use efficiency in alfalfa and found that $\Delta$ differed significantly among 18 alfalfa accessions. Their results suggested that $\Delta$ could be used to evaluate water-use efficiency in alfalfa.

Additional background information about $\Delta$ and its inheritance is required before $\Delta$ can be effectively utilized in alfalfa improvement programs. Accordingly, we designed a series of 5 experiments to determine genetic variation for $\Delta$ in representative alfalfa breeding populations, the effect of drought on $\Delta$, magnitudes of heritability for $\Delta$, genetic regulation of $\Delta$, and how $\Delta$ differs in various plant parts of alfalfa.

\section{Materials and Methods}

\section{Rainout Shelter Experiments}

Thirty randomly selected clones of alfalfa [ 15 clones each from the broad-based NC-83-1 germplasm (Kehr et al. 1975) and the cultivar 'Spredor 2'] were vegetatively propagated in a greenhouse during the winter of 1984-85 and transplanted in May 1985 to the Utah State University Evans Farm, approximately $2 \mathrm{~km}$ south of Logan, Utah. The soil at the site is a Nibley silty clay loam (fine, mixed, mesic Aquic Argiustoll). The site is equipped with an automated rainout shelter facility (modified after Upchurch et al. 1983) that automatically moves over the plot area when it rains or snows and excludes precipitation from the plot area. After the precipitation event, the shelter is automatically moved from the plots, exposing the plot area to ambient environmental conditions. A line-source sprinkler system (Hanks et al. 1976) specifically designed for a $10-\mathrm{m}$ by $47-\mathrm{m}$ plot area (Willardson et al. 1987) was used in the rainout shelter to control water application to the plot area. Water application was uniform along the length of the sprinkler line, but was high adjacent to the line and decreased to near 0 at about $5 \mathrm{~m}$ perpendicular from the sprinkler line. Consequently, this system exposed plants to a gradient of water application in a field environment.

Individual plots were established perpendicular to the linesource sprinkler system and were comprised of 1 row of 14 propagules of a single clone or genotype. Propagules were spaced at $30 \mathrm{~cm}$ within a row, and rows were $60 \mathrm{~cm}$ apart. Propagules on each end of the rows were designated as border plants. Although a total of 6 water treatment levels were defined $(1=$ wettest, $6=$ driest) with 2 propagules/clone contained in each level, only 3 water levels were used in this study $(1,3$, and 5$)$. The plots were arranged in a modified split-plot design with the 30 clones as whole plots and the 6 water levels as subplots. The design was replicated 4 times, twice on each side of the line-source irrigation pipe. For this study only 2 replications on 1 side of the irrigation pipe were sampled.

During the establishment year (1985), plots were irrigated uniformly as required for optimum growth. Plots were hand clipped 3 times (June, July, and August) in 1985. In 1986 plots were irrigated with the line-source system from April through October. A total of 1,24 , and $52 \mathrm{~cm}$ of irrigation water were applied to the 3 water levels that were sampled.

Plants were hand clipped to a 6-cm stubble height on 10-11 June, 14-15 July, and 21-22 August in 1986. Samples were dried at $70^{\circ} \mathrm{C}$ in a forced-air oven to obtain plant dry weights. The largest, most fully expanded leaves in the upper $15 \mathrm{~cm}$ of the canopy of each plant were removed from the shoots and ground to pass a 1-mm screen. Samples were analyzed for carbon isotope composition on a dual-inlet, double-collector gas isotope mass spectrometer following complete sample combustion. The carbon isotope ratio was calculated by comparing the ${ }^{13} \mathrm{C}$ to ${ }^{12} \mathrm{C}$ composition of the sample relative to the Pee Dee belemnite standard. These carbon isotope ratios were used to calculate $\Delta$ using a value of $-8 \%$ for the carbon isotope ratio for air (Mook et al. 1983), as described by Farquhar et al. (1989).

Data were analyzed using a split-split plot analysis following the procedures recommended by Hanks et al. (1980) for linesource irrigation experiments. Water levels were considered as fixed variables, and harvest/year and clones were considered as random variables. Approximate F tests were required in the combined analysis of variance.

\section{Genetic Variability Experiment}

Twenty-five plants were randomly selected within a field plot of NC-83-1 alfalfa (Kehr et al. 1975). Multiple stem cuttings were obtained from each plant during May 1985 and were grown in pots in the greenhouse. On 20 August 1986, these clonal propagules of the 25 lines were transplanted to the Utah State University Evans Experimental Farm. Plots consisted of individual propagules spaced $0.5 \mathrm{~m}$ apart within a row and $1 \mathrm{~m}$ between rows. The plot was bordered on all sides by other NC-83-1 clonal propagules. The experimental design was a randomized complete block with 5 replications; however, only 3 replications were sampled in the second year of the study. Plots were hand clipped to a 6-cm stubble height 3 times each growing season (June, July, and Sept.) and were not irrigated after the year of establishment. In 1988 (20-21 July) and 1989 (31 July-1 Aug.), the largest, most fully expanded leaves in the upper $15 \mathrm{~cm}$ of the canopy of each plant were removed from the shoots, dried at $70^{\circ} \mathrm{C}$ in a forced-air oven to a constant weight, and ground to pass through a $1-\mathrm{mm}$ screen.

After determination of $\Delta$ (described above), data were subjected to analysis of variance. Broad-sense heritability values were computed on a mean basis as the ratio $\sigma_{\mathrm{c}}{ }^{2} / \sigma_{\mathrm{ph}}^{2}$ where $\sigma_{\mathrm{c}}{ }^{2}$ is the variance component arising from differences among clones, and $\sigma^{2}$ ih is the phenotypic variance among the clones or the variance of a clonal mean. In the computation of variance components, clones and years were considered as random variables. Approximate F-tests were required in analyses combined across years.

\section{Alfalfa Variety Trial}

This experiment was conducted in conjunction with an irrigated alfalfa trial that was established near Morgan, Utah. On 30 April and 1 May 1981 a total of 90 alfalfa cultivars or elite breeding lines were seeded in 5-row plots (6.1 m length) with $15.2 \mathrm{~cm}$ spacing between rows. The experimental design was a randomized complete block with 4 replications. The soil is a Yeates Hollow loam series, which is classified as a clayey-skeletal, montmorillonitic, frigid typic Argixeroll. This trial was part of a collaborating farmer's field, which was subjected to a 3-cut, 30- 
35 day harvest schedule. The farmer sprinkler irrigated on a 1014 day rotation depending on water availability. On 17 July 1986 the second crop was harvested with a plot harvester at the latebud/early flower stage. Shoots were randomly selected from the harvested material from 78 of the cultivars or elite breeding lines in the trial. The samples were dried at $70^{\circ} \mathrm{C}$ in a forced-air oven to constant weight. The largest, most fully expanded leaves in the upper $15 \mathrm{~cm}$ of the canopy of each plant were removed from the shoots and ground to pass through a $1-\mathrm{mm}$ screen. Because the farmer inadvertently harvested a portion of the trial prior to our sampling, the fourth replication was not available for 11 of the 78 entries. After determination of $\Delta$, data were subjected to analysis of variance procedures using the General Linear Model (GLM) statistical package for unbalanced data (SAS Institut., Gary, N.C.).

\section{Diallel Experiment}

All 196 possible mating combinations (including self and reciprocal crosses) were made among 14 alfalfa plants selected at random from the NC-83-1 breeding population (Kehr et al. 1975). Seed from each cross was germinated, and seedlings were grown in a soil-peatmoss mixture (3:1) in cone-shaped plastic containers (21 cm length $\times 4 \mathrm{~cm}$ diameter at the top). The greenhouse regime was $30 / 15^{\circ} \mathrm{C}$ day/night temperature, natural daylength (ranging from 8 to 14 hours), and a daily watering schedule. Six replications of single plants from each cross were transplanted to a field location near Logan, Utah, on 9 May 1985 (approximately 140 days after germination). The experimental design was a randomized complete block with 1 -m spacing between plants. Only 3 replicates were sampled for this study. The plants were allowed 1 year for establishment, and no irrigation was applied after the establishment year. The first growth of the established plants was clipped and discarded in mid-June 1986 . On 16-18 July 1986, the largest, most fully expanded leaves in the upper $15 \mathrm{~cm}$ of the canopy of each plant were removed from the shoots, dried at $70^{\circ} \mathrm{C}$ in a forced-air oven to constant weight, and ground to pass a l-mm screen. After $\Delta$ determination, combining ability effects for $\Delta$ were calculated according to method I, model II (random model) of Griffing (1956). General and specific combining abilities were calculated according to method II, model I (fixed model) of Griffing (1956).

\section{Plant Part Experiment}

Two clones of alfalfa from the broad-based NC-83-1 germplasm and 2 clones from the cultivar 'Spredor 2,' which appeared to exhibit different (though not statistically different) $\Delta$ responses, were used in this experiment. These 4 clones were included in the 30 clones evaluated in the rainout shelter experiment, and the same plots described above for that study were used in this experiment. Four replications and 2 water levels (1 and 5) were sampled. In 1992 irrigation water was applied to the plots from April through October; $121 \mathrm{~cm}$ of water were applied for water level 1 and $17 \mathrm{~cm}$ for water level 5 .

Plants were clipped to a 6-cm stubble height on 4-5 June 1992, and clippings were discarded. On 21-22 July 1992 plants were harvested at a $6-\mathrm{cm}$ stubble height and separated into upper leaves, lower leaves, and stems. In addition, some shoot samples were kept intact to obtain an overall $\Delta$ for the entire shoot. Samples were dried at $70^{\circ} \mathrm{C}$ in a forced-air oven to constant weight and ground to pass through a 1-mm screen. After determination of $\Delta$ (described above) for various plant conponents, data were analyzed using a split-split plot analysis of variance.

\section{Results and Discussion}

\section{Rainout Shelter Experiment}

The 30 clones of alfalfa did not differ significantly for $\Delta$, either when data from each harvest were analyzed separately or when data were combined across harvests (Table 1). In comparing the 15 clones of the NC-83-1 population to the 15 clones from the 'Spredor 2' cultivar, the 2 populations differed $(P<0.05)$ only for Harvest 1 (data not shown). No population differences were observed for the second or third harvests or in the combined analysis of the data. These results indicated that the clones used in our experiment, which came from NC-83-1 germplasm and 'Spredor 2', did not exhibit consistent, reproducible differences in $\Delta$. The NC-83-1 germplasm (Kehr et al. 1975) is particularly broad based with one of its main sources from 94 cultivars, including experimental synthetics, breeding populations, and released germplasms adapted to the northern USA, and the other primary source consisting of 36 foreign plant introductions. Because alfalfa is a heterogenic, cross-pollinated species, considerable genetic variation typically is observed for most morphological and physiological characteristics and would have been expected for $\Delta$, particularly among the clones from the NC-83-1 germplasm.

Table 1. Degrees of freedom (df) and significance levels for the sources of variation for $\Delta$ in the split-plot ANOVA for individual harvests and combined data for the rainout shelter experiment.

\begin{tabular}{|c|c|c|c|c|c|}
\hline \multirow[b]{2}{*}{ Source } & \multirow[b]{2}{*}{$\mathrm{df}$} & \multicolumn{3}{|c|}{ Harvest dates } & \multirow[b]{2}{*}{ Combined } \\
\hline & & $6 / 86$ & $7 / 86$ & $8 / 86$ & \\
\hline Clones (C) & 29 & NS & NS & NS & NS \\
\hline Water level (W) & 2 & $\mathrm{NV} \dagger$ & NV & NV & NV \\
\hline$C \times W$ & 58 & $* *$ & NS & NS & NS \\
\hline Harvests $(\mathrm{H})$ & 2 & & & & ** \\
\hline $\mathrm{C} \times \mathrm{H}$ & 58 & & & & $* *$ \\
\hline $\mathrm{W} \times \mathrm{H}$ & 4 & & & & ** \\
\hline $\mathrm{C} \times \mathrm{W} \times \mathrm{H}$ & 116 & & & & NS \\
\hline
\end{tabular}

\#* NS Significant at the 0.01 level of probability and not significant, respectively. $\dagger \mathrm{NV}=$ No valid F-test for water levels.

Although the F-test for water levels was not strictly valid because water treatments were not randomly placed along the line-source water application gradient, $\Delta$ differed markedly across water levels and was greatest in the highest water level and lowest in the drought treatment. The clone by water level interaction was significant for the first harvest, but not for the second or third harvests or in the combined analysis across harvests. Values of $\Delta$ differed by harvest: Harvest $2>$ Harvest $3>$ Harvest 1 . The significant clone by harvest interaction indicated that the $\Delta$ response of clones was not consistent between harvests. The water level by harvest interaction also was statistically significant.

\section{Genetic Variability Experiment}

The 25 clones from the NC-83-1 population evaluated in this experiment differed significantly $(P<0.01)$ in their $\Delta$ response in 1988,1989 , and in the combined analysis across years (Table 2 ). The overall mean for $\Delta$ was lower $(P<0.05)$ in 1988 than in 1989, 
Table 2. Summary of 1988 and $1989 \Delta$ data from 25 clones of NC-83-1 alfalfa grown near Logan, Utah.

\begin{tabular}{|c|c|c|c|}
\hline \multirow[b]{2}{*}{ Statistic } & \multicolumn{2}{|c|}{ Harvest year } & \multirow[b]{2}{*}{ Combined } \\
\hline & 1988 & 1989 & \\
\hline & $\cdots$ & $--(\% 0)-$ & - - - - \\
\hline Mean & 19.5 & 20.0 & 19.7 \\
\hline \multicolumn{4}{|l|}{ Range } \\
\hline Minimum & 18.9 & 19.2 & 19.1 \\
\hline Maximum & 20.4 & 21.1 & 20.7 \\
\hline Variance component $\dagger$ & 0.15 *** & $0.18^{* *}$ & $0.15^{* * *}$ \\
\hline Heritability $\ddagger$ & 0.86 & 0.82 & 0.81 \\
\hline Coefficient of variation $(\%)$ & 1.8 & 1.7 & 1.0 \\
\hline
\end{tabular}

and the range in $\Delta$ was greater in $1989(1.9 \%)$ than in 1988 $(1.5 \%$ ). Broad-sense heritabilities (the proportion of total phenotypic variance attributable to genotypic differences) were relatively high $(>0.80)$ and consistent between years. These high broad-sense heritabilities are consistent with those previously reported for wheat (Triticum aestivum L.) (Condon et al. 1987), peanut (Arachis hypogoea L.) (Hubick et al. 1988), crested wheatgrass (Agropyron desertorum [Fischer ex Link] Schultes) (Johnson et al. 1990), cowpea (Vigna unguiculata [L.] Walp.) (Hall et al. 1990), and barley (Hordeum vulgare L.) (Acevedo 1993). Coefficients of variation were always less than $2 \%$, reflecting high precision in $\Delta$ determinations.

The significant $(P<0.05)$ year by clone interaction in this experiment (data not shown) suggests that caution should be used when combining $\Delta$ data across years. Nevertheless the correlation between years for $\Delta$ values was significant and positive $(r=$ $0.80^{* *}$, df $=73, P<0.01$ ), indicating that clones performed quite consistently from 1 year to the next. This clonal consistency also is evident in the rankings of clones in each year. Eight of the 10 clones with the lowest $\Delta$ values in 1988 also were lowest in 1989; 9 out of the 10 clones with the highest $\Delta$ values were common to both years. This consistency in the performance of alfalfa clones across years or environments also was observed by Morgan et al. (1993) and Johnson and Tieszen (1994) and in cool-season perennial forage grasses by Read et al. (1992), Johnson (1993), and Johnson et al. (1993).

\section{Alfalfa Variety Trial}

The 78 alfalfa varieties evaluated in northern Utah differed significantly $(P<0.01)$ in their $\Delta$ response. However, the overall mean for $\Delta$ was $20.9 \%$ with a range of only $0.8 \%$, from $20.4 \%$ o for 'Haymaker' to $21.2 \%$ for 'Deseret' (Table 3). This was a surprisingly narrow range of $\Delta$ in this large group of 78 U.S cultivars. Johnson and Tieszen (1994) found a range of $1.4 \%$ among 18 alfalfa accessions from around the world that were grown in irrigated and dryland field environments in southeastern Washington, although they did not detect significant differences among the 4 U.S. alfalfa cultivars included in their study. Our range in $\Delta$ also was smaller than the 1.1 to $1.5 \%$ o range for 11 clones of yellow-flowered alfalfa (Medicago sativa subsp. falcata [L.] Arcang.) grown in northern Colorado (Morgan et al. 1993). Based on our results and those of Johnson and Tieszen (1994), variability for $\Delta$ apparently is limited among U.S. alfalfa culti-
Table 3. Alfalfa cultivars and advanced breeding lines evaluated for $\Delta$ in irrigated trial conducted at Morgan, Utah. Cultivars or lines are in descending order of $\Delta$ with Deseret having $\Delta=21.2 \%$ and Haymaker having $\Delta=20.4 \%$ ( $(n=3$ or 4$)$.

\begin{tabular}{|c|c|c|c|}
\hline Deseret & Valor & Hay Future $\dagger$ & AS- $67 \dagger$ \\
\hline Pacer & WL-309† & Hay Future & Agate \\
\hline C/W 67 & Coop. F24OA & Ranger & Dawson \\
\hline Wash. Syn. I & Vernal & Resist. II & Pi 545 \\
\hline $20-30$ & Lahonton & Apollo & Gladiator \\
\hline WL $312 \dagger$ & Action & AS-13 & ATC \\
\hline WL-310 & AS-49 & Super 721 & AS-67 \\
\hline AS-49R & Classic & Kanza & C/W 8642 \\
\hline WVL-318† & WL-309 & CNW 634 & Blazer \\
\hline Thor & Tempo & Pi 532 & Hì-phy \\
\hline Anchor & WV-318 & $\mathrm{C} / \mathrm{WV} 62$ & Riley \\
\hline Vangard $t$ & Vangard & ATRA 55 & WL 315 \\
\hline Washoe & Anchort & AS-13† & Phytor \\
\hline Citation & AS-49R $t$ & WVL 220 & SC400A \\
\hline Pi 581 & AS-63 & Baker & C/W 637 \\
\hline Nev. Syn. XX & Weevlchek & WL 316 & RS-209t \\
\hline $919(20)$ & WL 314 & Pi 524 & Spredor 2 \\
\hline Trident & WL 312 & Pacert & Haymaker \\
\hline Cascade & C/V 69 & $6-7730$ & \\
\hline Valort & 167 & Apollo't & \\
\hline
\end{tabular}

$\dagger$ Denotes pelleted seed.

vars. Given the greater variation observed for $\Delta$ in alfalfa accessions from the U.S. National Plant Germplasm System (Johnson and Tieszen 1994, Morgan et al. 1993), breeding programs interested in selection of alfalfa genotypes with low $\Delta$ may have to be selected from alfalfa accessions from plant introductions rather than U.S. cultivars. Alternatively, the range of $\Delta$ values among our 78 alfalfa cultivars may have been greater if plants had been grown under water-limited conditions, as observed in clones of crested wheatgrass (Read et al. 1991, 1992).

Values of $\Delta$ were very reproducible across replications in our experiment, as evidenced by the overall coefficient of variation for $\Delta$ of less than $1 \%$. Similar to the results of Morgan et al. (1993), values of $\Delta$ were not related to green forage yield ( $\mathrm{r}=$ $-0.10)$.

\section{Diallel Experiment}

Values of $\Delta$ differed significantly $(P<0.01)$ among the 196 lines evaluated in this experiment (Table 4). Progeny means from the 14 parents ranged from 20.2 to $20.8 \%$, whereas the range for $\Delta$ was expectedly greater among the individual crosses (19.8 to $21.4 \%$ ). General combining ability was significant $(P<0.01)$, while specific combining ability and reciprocal effects were not.

Table 4. Degrees of freedom (df) and mean squares with indicated significance levels for the sources of variation from the analysis of variance for $\Delta$ in the NC-83-1 diallel experiment.

\begin{tabular}{lll}
\hline \hline Source & df & $\begin{array}{l}\text { Mean } \\
\text { square }\end{array}$ \\
\hline Crosses & 195 & $0.38^{* *}$ \\
General combining ability & 13 & $2.11^{* *}$ \\
Specific combining ability & 91 & 0.24 \\
Reciprocal & 91 & 0.26 \\
Error & 392 & 0.23 \\
\hline
\end{tabular}

** Significant at $P<0.01$. 
The significant mean square for general combining ability indicated that additive genetic variance among the parents was important in regulating $\Delta$ response in this population of alfalfa. The nonsignificant mean square for specific combining ability indicated that non-additive genetic variance, such as dominance or epistasis, was not important for $\Delta$ response. The nonsignificant reciprocal effect indicated that nonnuclear DNA did not contribute to the genetic regulation of $\Delta$ response. Broad-sense heritabilities of the half-sib families of the 14 clones serving as the female parent were 0.86 , suggesting that the $\Delta$ response in this population of alfalfa is very amenable to selection.

Few experiments have used diallel analysis to evaluate inheritance characteristics of $\Delta$ in plants. However, White (1993) crossed 8 parents of common bean (Phaseolus vulgaris L.) in a diallel without reciprocals and evaluated the $F_{2}$ and $F_{3}$ populations for leaf $\Delta$. Mean squares for general combining ability were generally larger than those for specific combining ability, suggesting that additive gene action also was important in common bean. Similar conclusions concerning inheritance of $\Delta$ were reached by Ehdaie et al. (1993) in wheat where significant additive variation was present for $\Delta$. They concluded that $\Delta$ is a complex trait that is quantitatively inherited. Hall et al. (1993) compared $F_{1}$ hybrids from reciprocal crosses and parents of cowpea and found that differences in $\Delta$ involved nuclear rather than maternal inheritance. Read et al. (1993) found that narrow-sense (realized) heritabilities for $\Delta$ in crested wheatgrass exceeded 0.75 and that correlations between progeny means for $\Delta$ and means of the corresponding midparents were significant. The results of our present experiment along with these other inheritance studies suggest that $\Delta$ can be effectively manipulated through standard breeding techniques that typically are used for other quantitatively inherited traits. However, a more genetically diverse collection of alfalfa genotypes than the $14 \mathrm{NC}-83-1$ parents used in our experiment probably would be necessary.

\section{Plant Part Experiment}

Significant differences $(P<0.01)$ were detected among clones and plant parts in this experiment (Table 5), which we expected

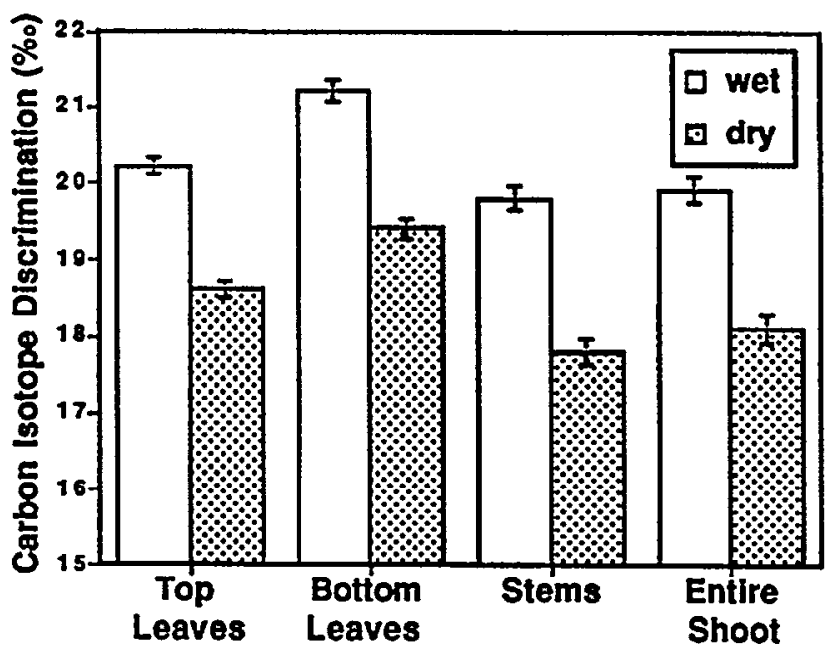

Fig. 1. Carbon isotope discrimination $(\Delta)$ of top leaves, bottom leaves, stems, and entire shoot for 4 alfalfa clones grown under 2 water levels in rainout-sheltered plots $(n=4)$.
Table 5. Degrees of freedom (df) and mean squares with indicated significance levels for the sources of variation from the analysis of variance for $\Delta$ in the plant part experiment.

\begin{tabular}{llc}
\hline \hline Source & df & $\begin{array}{c}\text { Mean } \\
\text { square }\end{array}$ \\
\hline Entry (E) & 3 & $3.82^{* * *}$ \\
Water level (W) & 1 & $92.49 \mathrm{NV}$ t \\
E $W$ & 3 & 0.41 \\
Plant part (P) & 3 & $11.69^{* *}$ \\
E $\times P$ & 9 & 0.22 \\
W $\times P$ & 3 & 0.12 \\
E $\times W \times P$ & 9 & 0.06 \\
\hline
\end{tabular}

F* Significant at the 0.01 level of probability.

$\dagger N V=$ No valid $F$-test for water levels.

because the 4 clones were selected for their divergent $\Delta$ values. Stems had the lowest $\Delta$ followed by the entire shoot, upper leaves, and bottom leaves (Fig. 1). The $\Delta$ values for the entire shoot were between those for the leaves and stems, but were closest to $\Delta$ values of the stem, probably reflecting the large proportion of stem in the whole plant sample. The lower leaves developed during the early, cool portion of the growing season whereas the upper leaves grew during the hot, dry part of the growing season. Presumably, stomata were more open during the development of the lower canopy leaves than those in the upper canopy, resulting in a greater $\Delta$ in the lower leaves. Besides environmental effects, variation in $\Delta$ among various plant parts may also be due to differences in diffusional constraints (Farquhar et al. 1989), chemical composition (O'Leary 1981), ratio of assimilation rate to $\mathrm{CO}_{2}$ diffusive conductance (Farquhar et al. 1989), photosynthetic metabolism (Wirth et al. 1977), and anatomical characteristics (Araus et al. 1992).

Even though the comparison between water levels is not strictly valid because water treatments were not randomly placed, drought markedly decreased $\Delta$ values for all plant parts (Fig. 1). This agrees with results for alfalfa (Morgan et al. 1993, Johnson and Tieszen 1994) and many other species where drought typically reduces $\Delta$ because of lowered stomatal conductance, and for some species, a concomitant decline in photosynthetic capacity (Farquhar et al. 1989, Hall et al. 1990, Johnson et al. 1990, White 1993). Although plant parts differed in $\Delta$, the clone by plant part and water level by plant part interactions were not significant. This indicated that even though the magnitude of $\Delta$ differed among the various plant parts, the relative $\Delta$ response was similar across clones or water levels. This suggests that any of the 3 plant parts or the entire shoot could be used to characterize $\Delta$ in alfalfa clones. Given the time and labor required to separate individual plant parts, the entire shoot may be the fastest and most economical sample to obtain and analyze for $\Delta$ in alfalfa breeding programs.

In summary, except for the rainout shelter experiment, our series of experiments showed that genetic variation for $\Delta$ existed within alfalfa and that broad-sense heritabilities for $\Delta$ exceeded 0.80 . The narrow range of $\Delta$ values observed among the 78 U.S. cultivars grown under irrigation suggested that it may be necessary to use alfalfa plant introductions from the U. S. National Plant Germplasm System to increase diversity in $\Delta$ response. The results of the diallel experiment showed that additive genetic variance among parents was important in the inheritance of $\Delta$ and that it should be possible to effectively manipulate $\Delta$ response in alfalfa through standard breeding techniques. Although plant 
parts differed in $\Delta$, similarities in $\Delta$ response in plant parts across clones or water levels suggested that any plant part could be used consistently to characterize $\Delta$ in alfalfa breeding programs. Our results suggest that $\Delta$ may be a beneficial criterion for breeding and selecting alfalfa cultivars that use water efficiently under water-limited conditions. However, additional data concerning the physiological basis of $\Delta$ response, relationship of $\Delta$ to plant water status, and association between $\Delta$ and forage yield in alfalfa are required to document that selection for low $\Delta$ would lead to significant gains in water-use efficiency in alfalfa.

\section{Literature Cited}

Acevedo, E. 1993. Potential of carbon isotope discrimination as a selection criterion in barley breeding, p. 399-417. In: J. R. Ehleringer, A. E. Hall, and G. D. Farquhar (ed.), Stable isotopes and plant carbon-water relations. Academic Press, San Diego, Calif.

Araus, J.L., P. Santiveri, D. Bosch-Serra, C. Royo, and I. Romagosa. 1992. Carbon isotope ratios in ear parts of Triticale. Plant Physiol. 100:1033-1035.

Barnes, D.K., B.P. Goplen, and J.E. Baylor. 1988. Highlights in the USA and Canada, p. 1-24. In: A. A. Hanson, D. K. Barnes, and R. R. Hill, Jr. (ed.), Alfalfa and alfalfa improvement, No. 29 in Agronomy Series. Amer. Soc. Agron., Madison, Wisc.

Briggs, LJ. and H.L. Shantz. 1914. Relative water requirements of plants. J. Agr. Res. 3:1-64.

Cole, D.F., A.K. Dobrenz, M.A. Massengale, and L.N. Wright. 1970. Water requirement and its association with growth components and protein content of alfalfa (Medicago sativa $\mathrm{L}$.). Crop Sci. 10:237-240.

Condon, A.G., R.A. Richards, and G.D. Farquhar. 1987. Carbon isotope discrimination is positively correlated with grain yield and dry matter production in field-grown wheat. Crop Sci. 27:996-1001.

Ehdaie, B., D. Barnhart, and J.G. Waines. 1993. Genetic analyses of transpiration efficiency, carbon isotope discrimination, and growth characters in bread wheat, p. 419-434. In: J. R. Ehleringer, A. E. Hall, and G. D. Farquhar (ed.), Stable isotopes and plant carbon-water relations. Academic Press, San Diego, Calif.

Ehleringer, J.R., A. E. Hall, and G.D. Farquhar. 1993. Stable isotopes and plant carbon-water relations. Academic Press, San Diego, Calif.

Farquhar, G. D., J. R. Ehleringer, and K.T. Hubick. 1989. Carbon isotope discrimination and photosynthesis. Annu. Rev. Plant Physiol. Plant Mol. Biol. 40:503-537.

Farquhar, G.D., M. H. O'Leary, and J.A. Berry. 1982. On the relationship between carbon isotope discrimination and the intercellular carbon dioxide concentration in leaves. Aust. J. Plant Physiol. 9:121-137.

Farquhar, G.D. and R.A. Kichards. 1984. Isotopic composition of plant carbon conelates with water-use efficiency of wheat genotypes. Aust. J. Plant Physiol. 11:539-552.

Griffing, B. 1956. Concept of general and specific combining ability in relation to diallel crossing systems. Aust. J. Biol. Sci. 9:463-493.

Hall, A.E., A. M. Ismail, and C. M. Menendez. 1993. Implications for plant breeding of genotypic and drought-induced differences in water-use efficiency, carbon isotope discrimination, and gas exchange, p. 349-369. In: J. R. Ehleringer, A. E. Hall, and G. D. Farquhar (ed.), Stable isotopes and plant carbon-water relations. Academic Press, San Diego, Calif.

Hall, A.E., R.G. Mutters, K. T. Hubick, and G. D. Farquhar. 1990. Genotypic differences in carbon isotope discrimination by cowpea under wet and dry field conditions. Crop Sci. 30:300-305.

Hanks, R.J., J. Keller, and G. D. Wilson. 1976. Line source sprinkler for continuous variable irrigation-crop production studies. Soil Sci. Soc. Amer. Proc. 40:426-429.

Hanks, R.J., D.V. Sisson, R. L. Hurst, and K. G. Hubbard. 1980. Statistical analysis of results from experiments using the line-source sprinkler system. Soil Sci. Soc. Amer. J. 44:886-888.

Hubick, K.T., R. Shorter, and G.D. Farquhar. 1988. Heritability and genotype $x$ environment interactions of carbon isotope discrimination and transpiration efficiency in peanut (Arachis hypogaea L.). Aust. J. Plant Physiol. 15:799-813.

Johnson, D.A. and K.H. Asay. 1993. Viewpoint: Selection for improved drought response in cool-season grasses. J. Range Manage. 46:194-202.

Johnson, D.A., K.H. Asay, and J.J. Read. 1993. Genotypic and environmental variation for carbon isotope discrimination in crested wheatgrass, a perennial forage grass, p. 269-280. In: J. R. Ehleringer, A.E. Hall, and G. D. Farquhar (ed.), Stable isotopes and plant carbon-water relations. Academic Press, San Diego, Calif.

Johnson, D.A., K.H. Asay, L.L. Tieszen, J.R. Ehleringer, and P.G. Jefferson. 1990. Carbon isotope discrimination: Potential in screening cool-season grasses for water-limited environments. Crop Sci. 30:338-343.

Johnson, D.A. and M.D. Rumbaugh. 1981. Nodulation and acetylene reduction by certain rangeland legume species under field conditions. J. Range Manage. 34:178-181.

Johnson, R.C. 1993. Carbon isotope discrimination, water relations, and photosynthesis in tall fescue. Crop Sci. 33:169-174.

Johnson, R.C. and L.L. Tieszen. 1994. Variation for water-use efficiency in alfalfa germplasm. Crop Sci. 34:452-458.

Kehr, W.R., D.K. Barnes, E.L. Sorensen, W.H. Skrdla, C.H. Hanson, D. A. Miller, T. E. Thompson, I.T. Carlson, L.J. Elling, R.L. Taylor, M. D. Rumbaugh, E.T. Bingham, D.E. Brown, and M.K. Miller. 1975. Registration of alfalfa germplasm pools NC-83-1 and NC-83-2. Crop Sci. 15:604-605.

Michaud, R., W.F. Lehman, and M.D. Rumbaugh. 1988. World distribution and historical development, p. 25-91. In: A. A. Hanson, D. K. Barnes, and R. R. Hill, Jr. (ed.), Alfalfa and alfalfa improvement, No. 29 in Agronomy Series. Amer. Soc. Agron., Madison, Wisc.

Miles, A.D. 1969. Alfalfa as a range legume. J. Range Manage. 22:205-207.

Mook, W.G., M. Koopmans, A.F. Carter, and C.D. Keeling. 1983. Seasonal, latitudinal, and secular variations in the abundance and isotopic ratios of atmospheric carbon dioxide. 1. Results from land stations. J. Geophys. Res. 88:10915-10933.

Morgan, J.A., D.R. Lecain, and C.E. Townsend. 1993. Carbon isotope discrimination and productivity of yellow-flowered falcata alfalfa clones, $p$. 156-157. In: Proc. XVII Internat. Grassland Congress. Keeling and Mundy Ltd., Palmerston North, New Zealand.

O'Leary, M.H. 1981. Carbon isotope fractionation in plants. Phytochemistry 20:553-567.

Read, J.J., K.H. Asay, and D.A. Johnson. 1993. Divergent selection for carbon isotope discrimination in crested wheatgrass. Can. J. Plant Sci. 73:1027-1035.

Read, J.J., D.A. Johnson, K.H. Asay, and L.L. Tieszen. 1991. Carbon isotope discrimination, gas exchange, and water-use efficiency in crested wheatgrass clones. Crop Sci. 31:1203-1208.

Read, J.J., D.A. Johnson, K.H. Asay, and L.L. Tieszen. 1992. Carbon isotope discrimination: Relationship to yield, gas exchange, and water-use efficiency in field-grown crested wheatgrass. Crop Sci. 32:168-175.

Rumbaugh, M.D. 1982. Reseeding by eight alfalfa populations in a semiarid pasture. J. Range Manage. 35:84-86.

Rumbaugh, M.D., D.A. Johnson, and G.H. Van Epps. 1982. Forage yield and quality in a Great Basin shrub, grass, and legume pasture experiment. J. Range Manage. 35:604-609.

Rumbaugh, M.D. and M.W. Pedersen. 1979. Survival of alfalfa in five semiarid range seedings. J. Range Manage. 32:48-51.

Rumbaugh, M.D. and C.E. Townsend. 1985. Range plant improvement in western North America, p. 29-39. In: J. R. Carlson and E. D. McArthur (Chrmn.). Proc. Symp. at Annual Meeting of Soc. Range Manage., Salt Lake City, Utah, Feb. 14, 1985. Soc. Range Manage., Denver, Colo.

Sheaffer, C.C., C.B. Tanner, and M.B. Kirkham. 1988. Alfalfa water relations and irrigation, p. 373-409. In: A. A. Hanson, D. K. Barnes, and R. R. Hill, Jr. (ed.), Alfalfa and alfalfa improvement, No. 29 in Agron. Series. Amer. Soc. Agron., Madison, Wisc.

Upchurch, D.R., J.T. Ritchie, and M.A. Foale. 1983. Design of a large dual-structure rainout shelter. Agron. J. 75:845-848.

White, J.W. 1993. Implications of carbon isotope discrimination studies for breeding common bean under water deficits, p. 387-398. In: J. R. Ehleringer, A. E. Hall, and G. D. Farquhar (ed.), Stable isotopes and plant carbon-water relations. Academic Press, San Diego, Calif.

Willardson, L.S., D.M. Oosterhuis, and D.A. Johnson. 1987. Sprinkler selection for line-source irrigation systems. Irrig. Sci. 8:65-76.

Wilton, A.C., R.E. Ries, and L. Hoffman. 1978. The use and improvement of legumes for ranges. North Dakota Agr. Exp. Sta. Farm Res. 29-31.

Wirth, E., G.J. Kelley, G. Fischbeck, and E. Latzko. 1977. Enzyme activities and products of $\mathrm{CO}_{2}$ fixation in various photosynthetic organs of wheat and oat. Z. Pflanzenphysiol. 82:78-87. 